\title{
CHANGES IN GROWTH SEASONALITY THROUGHOUT Netuma barba (LACÉPÈDE, 1803) (SILURIFORMES, ARIIDAE) ONTOGENY
}

\author{
VELASCO, G. ${ }^{1}$ and REIS, E. G. ${ }^{2}$ \\ ${ }^{1}$ Pós-graduação em Oceanografia Biológica, Fundação Universidade Federal do Rio Grande, FURG, \\ C.P. 474, CEP 96201-900, Rio Grande, RS, Brazil \\ ${ }^{2}$ Departamento de Oceanografia, Fundação Universidade Federal do Rio Grande, FURG, \\ C.P. 474, CEP 96201-900, Rio Grande, RS, Brazil \\ Correspondence to: Gonzalo Velasco, Departamento de Oceanografia, Fundação Universidade Federal do Rio \\ Grande, FURG, C.P. 474, CEP 96201-900, Rio Grande, RS, Brazil, e-mail: pgobgvc@ @urg.br \\ Received June 16, 2003 - Accepted January 19, 2004 - Distributed November 30, 2004
}

(With 1 figure)

The somatic and populational growth of living organisms is affected directly and indirectly by the environment (Nikolskii, 1969; Weatherley, 1972; Pauly, 1984; Margalef, 1995). A direct effect is metabolism change (much more apparent in ectotherm organisms); indirect effects include variable food availability and differing vulnerability to predation since temperature and other physical variables cause cycles in ecosystem productivity as well as migration in some competitor and predator species (Margalef, 1995). This is more clearly observed in long-lived organisms (Nikolskii, 1969; Weatherley, 1972; Pauly, 1984).

It is commonly accepted that individual growth in temperate water fishes shows some degree of oscillation during the year, following temperature or other environmental cycles like day length, rain seasonality, moon cycle, etc. Most somatic growth models do not include such information about this type of variation or oscillation and more simple but useful models are generally used such as the von Bertalanffy growth function (Casselman, 1983; Pauly, 1984; Moreau, 1987; Sparre et al., 1989).

In medium- and high-latitude ecosystems, the warm season causes an increase in the individual growth rate with a decrease, reaching zero in some groups of fishes, occurring in the cold season (Pauly, 1984; Sparre et al., 1989). In such cases, growth in some groups may be conveniently described by a kind of sine-wave growth curve for a one-year period (Pauly, 1984). This pattern is believed to represent the life cycle of all the species.

For the semi-anadromous catfish Netuma barba (Lacépède, 1803) (Siluriformes, Ariidae) the growth cycle appears to be different. Length frequency analysis and modal progression analysis for juveniles $(\mathrm{n}=$ 38.838; Velasco, 1998) in the Patos lagoon estuary, southern Brazil showed the expected pattern: fast growth in the warmer months (October-April) and slow growth in the colder months (May-September) (Fig. 1). However, the adult fraction of the population showed a quite different behaviour. Reis $(1982,1986 \mathrm{a})$ studied growth of adult catfish from artisanal fishery catches. Lapillus otolith structure showed that the greatest increment of material deposition (calcium and protein; see Casselman, 1983) occurs in winter.

What factor could affect adult catfish growth more than the cold season itself? The species biology may be the answer. Juveniles up to three years of age inhabit the estuarine area of Patos lagoon for feeding and further development (Araújo, 1983; Velasco, 1998). In this region, they are affected by temperature variations and the rain cycle: generally warm and dry summers (December-February) and cold and rainy winters (June-August) (Seeliger et al., 1997). These variations induce metabolic changes as reflected in the cohort mean-size analysis shown in Fig. 1, where a decrease in the growth rate is evident during the colder months. This is specially clear for the strong 1979 cohort, followed during two years.

Pre-adult (3 to 7-years-old) and adult (age 7 up) Netuma barba spend autumn and winter feeding on the continental shelf. Some of these individuals are caught by the trawler fleet in southern Brazil and adjacent regions (southeastern Brazil, Uruguay, and Argentina) (Reis, 1986a; Haimovici, 1997; Velasco, 1998). In spring (September-November) the mature individuals start to enter the estuary for reproduction, which takes place around November. After that, females leave the estuary followed by the males that carry the developing embryos in their oral cavity for protection (Reis, 1986b). During this period, which may last up to 2 months (Rimmer \& Merrick, 1982; Reis, 1986b), male adults do not feed.

We believe the stress caused by the environmental change from marine to brackish water, coupled with the absence of feeding activity, causes the low growth 


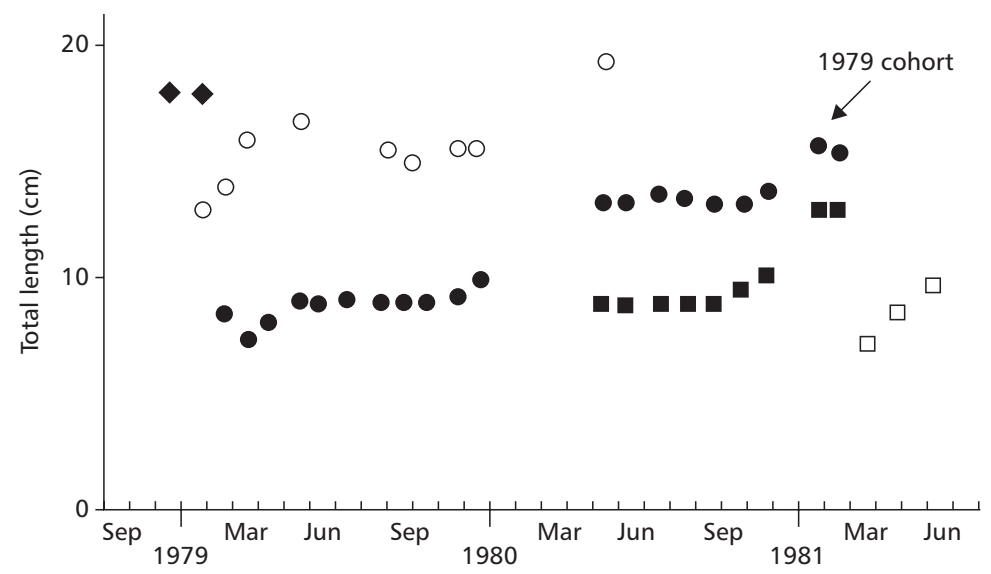

Fig. 1 - Cohort mean-size analysis (total length in $\mathrm{cm}$ ) for Netuma barba juveniles inside Patos lagoon estuary, southern Brazil (from Velasco, 1998). The 1979 cohort is represented by full circles. Different symbols represent different cohorts.

rate and low deposition of material in otoliths and other calcified structures (Reis, 1986a).

The absence of feeding activity is not only critical for incubating males, but also for the females, most of whose abdominal cavities are occupied by an ovary filled with very large eggs $(15 \mathrm{~mm} \varnothing)$ during maturation (Rimmer \& Merrick, 1982; Reis, 1986b). The poor physical condition of adults that leave the estuary shows how demanding the reproduction and incubation period is (Reis, 1986a, b).

The growth pattern presented by Netuma barba is different from what is known about other fishes. This change may be present in other organisms with similar biological characteristics and if so would lead to a new approach to fish growth and in creating mathematical models that include such variations.

Acknowledgements - The authors are grateful to Prof. Dr. J. P. Castello, MSc. D. Hellebrandt, and an anonymous referee for suggesting improvements in this manuscript.

\section{REFERENCES}

ARAÚJO, F. G., 1983, Distribuição, abundância, movimentos sazonais e hábitos alimentares de bagres marinhos (Siluriformes, Ariidae) no estuário da Lagoa dos Patos, RS, Brasil. MSc. Thesis, University of Rio Grande, Rio Grande, 89p.

CASSELMAN, J. M., 1983, Age and growth assessment of fish from their calcified structures - techniques and tools, pp. 1-17. In: E. D. Prince \& L. M. Pulos (eds.), Proceedings of the International Workshop on Age Determination of Oceanic Pelagic Fishes: Tunas, Billfishes and Sharks. NOAA Tech. Rep. NMFS, v. 8.

HAIMOVICI, M., 1997, Demersal and benthic Teleosts, pp. 129-136. In: U. Seeliger, C. Odebrecht \& J. P. Castello (eds.), Subtropical convergence environments: the coastal and sea in the Southwestern Atlantic. Berlin, Springer, Chap. 6.14.
MARGALEF, R., 1995, Ecología. Omega, Barcelona, 951p.

MOREAU, J., 1987, Mathematical and biological expression of growth in fishes: recent trends and further developments, pp. 81-113. In: R. C. Summerfeit \& G. E. Hall (eds.), The age and growth of fish. The Iowa State Univ. Press, Iowa.

NIKOLSKII, G. V., 1969, Theory of fish population dynamics as the biological background for rational exploitation and management of fishery resources.Oliver \& Boyd Ltd., Edimburg, 323p.

PAULY, D., 1984, Fish population dynamics in tropical waters: a manual for use with programmable calculator. ICLARM Studies and Reviews, Manila, Philippines, 8: 325.

REIS, E. G., 1982, Idade, crescimento e reprodução de Netuma barba (Siluriformes, Ariidae) no estuário da Lagoa dos Patos $(R S)$. MSc. Thesis, University of Rio Grande, Rio Grande, $114 \mathrm{p}$.

REIS, E. G., 1986a, Age and growth of the marine catfish, Netuma barba (Siluriformes, Ariidae), in the estuary of the Patos Lagoon (Brazil). Fisheries Bulletin, 84(3): 679-686.

REIS, E. G., 1986b, Reproduction and feeding habits of the marine catfish, Netuma barba (Siluriformes, Ariidae), in the estuary of the Patos Lagoon (Brazil). Atlântica, 8: 3555 .

RIMMER, M. A. \& MERRICK, J. R., 1982, A review of reproduction and development in the fork-tailed catfishes (Ariidae). Proceedings of the Limnologic Society of New South Wales, 107(1): 41-50.

SEELIGER, U., ODEBRECHT, C. \& CASTELLO, J. P. (eds.), 1997, Subtropical convergence environments: the coastal and sea in the Southwestern Atlantic. Springer, Berlin, 308p.

SPARRE, P., URSIN, E. \& VENEMA, S. C., 1989, Introduction to tropical fish stock assessment. Part 1: manual. FAO Fish. Tech. Paper n. 306.1. Rome, Italy, 337p.

VELASCO, G., 1998, Crescimento e mortalidade natural de Netuma barba (Lacépède, 1803) (Siluriformes, Ariidae) no estuário da Lagoa dos Patos, RS, Brasil. MSc. Thesis, University of Rio Grande, Rio Grande, 65p.

WEATHERLEY, A. H., 1972, Growth and ecology of fish populations. Academic Press, London, 293p. 